\title{
Groundwater Governance in Australia, the European Union and the Western USA
}

\author{
Andrew Ross
}

\begin{abstract}
Groundwater governance can be defined as the system of formal and informal rules, rule-making systems and actor networks at all levels of society that are set up to steer societies towards the control, protection and socially acceptable utilization of groundwater resources and aquifer systems. Groundwater resources are very diverse and groundwater governance is complicated by the common pool nature of most groundwater resources, information gaps, and the diversity of stakeholders and their interests. There are few comparative studies of groundwater governance. This chapter contributes to that literature by means of a high level comparison of groundwater governance in Australia, the European Union and the Western USA. The comparison is structured using the five categories of governance issues defined in the Earth System Governance Project; architecture, access and allocation, accountability, adaptiveness, and agency - defined in this case as management organisation. The EU WFD has gone furthest towards an integrated framework to manage groundwater quantity and quality objectives, but there are many implementation challenges. Australia's system of annually adjustable water entitlements and related water markets provides security, efficiency and flexibility but it is not yet clear how successfully environmental water allocations can be integrated within this framework. The system of prior appropriation in the Western US provides clearly defined priorities for water allocation, but lacks flexibility during extreme droughts. Fully integrated groundwater management, as intended by the WFD, is a very ambitious goal. The advantages of a strong central direction and coordination together with decentralised local management could be obtained through
\end{abstract}

\footnotetext{
A. Ross $(\bowtie)$

National Centre for Groundwater Research and Training, Fenner School of Environment and Society, Australian National University, Canberra, ACT, Australia e-mail: a.ross@unesco.org
} 
a decentralised system of collaborative planning and management at sub-basin scales nested within an overarching groundwater planning framework at the jurisdictional or basin scale. This system could take various forms in different countries depending on social preferences and institutional settings and capacity.

\subsection{Introduction}

Groundwater makes up $30 \%$ of the world's freshwater and $99 \%$ of the world's liquid freshwater. Groundwater supplies over $40 \%$ of global irrigation water and $50 \%$ of municipal water withdrawals. Two billion people depend on groundwater for drinking water. The consumption of groundwater is growing rapidly driven by increases in global population and agriculture and overextraction, and pollution of groundwater is increasing in many parts of the world. This is reducing groundwater reserves and harming rivers and lakes that are connected to groundwater (see Chap. 2 for more detail on the scale of the groundwater problem internationally). As groundwater is depleted supply costs increase leading to reduced access for the poor (Wijnen et al. 2012). Therefore good governance, protecting groundwater resources is crucial, for environmental, economic and social reasons.

Several features of groundwater and its use present challenges for its governance. Firstly, groundwater resources are not visible or well understood. The impacts of groundwater use and pollution are often hidden, and only become apparent over tens or even hundreds of years (Moench 2004, 2007; Wijnen et al. 2012). Secondly, groundwater governance has to allow and account for the large diversity of groundwater resources, users and use impacts. Groundwater is also subject to a diverse range of point source and diffuse pollution. Thirdly, groundwater is often subject to unsustainable levels of exploitation and depletion, because it is a common pool resource - individual users cannot exclude others (Ostrom 1990; Ostrom et al. 1994). Fourthly, even when individual groundwater users collaborate, they cannot be expected to manage remote impacts of groundwater pumping on other resources and the environment. Because of these features groundwater governance is a complex process that requires coordination across multiple spatial and time scales, sectors and administrative levels. Partnerships between governing authorities and water users are needed to address these problems (Schlager 2007; Blomquist and Schlager 2008).

The definition of groundwater governance in this chapter is adapted from the definitions in the Earth System Governance Project (Biermann et al. 2009) and the global diagnostic on groundwater governance (GEF et al. 2015). Groundwater governance is defined as the system of formal and informal rules, rule-making systems and actor networks at all levels of society that are set up to steer societies towards the control, protection and socially acceptable utilization of groundwater resources and aquifer systems.

There are few comparative studies of groundwater governance. This chapter contributes to that literature by means of a high level comparison of groundwater 
governance in Australia, the European Union and the Western USA. The comparison is structured using the five categories of governance issues defined in the Earth System Governance Project; architecture, access and allocation, accountability, adaptiveness and agency - defined in this case as management organisation.

The remainder of this chapter proceeds as follows. The next section introduces the importance and special features of groundwater. These features present a number of challenges for groundwater management. The following section discusses the challenges for groundwater governance in terms of the five issues defined in the Earth System Governance Project. The main part of the chapter includes a comparison of groundwater governance in Australia, the EU, and the western United States. This is followed by a summary assessment of the strengths and weaknesses of groundwater governance in the three regions and some governance difficulties and dilemmas.

\subsection{Framework for the Assessment of Groundwater Governance}

Groundwater governance involves collective action to ensure socially-sustainable utilisation and effective protection of groundwater resources for the benefit of people and groundwater dependent ecosystems (Foster et al. 2009). Groundwater governance as defined in this project refers to forms of steering societies that go beyond government policy-making and include a wide variety of decision-making structures and processes at all levels of society. These involve a wide variety of non-state actors representing industries, scientists, environmental interests and other parties interested in groundwater (Foster and Garduno 2013). In the remainder of this chapter groundwater governance is analysed using a framework based on the five issues defined in the Earth Systems Governance Project (Biermann et al. 2009).

The Earth Systems governance framework enables a large number of governance issues to be grouped into five major classes: architecture, access and use, accountability adaptation and agency and some links between the five issue classes are also established within the framework. Further details of this classification applied to groundwater are given in Table 6.1 and in the remainder of this section.

Table 6.1 Classification of earth system governance issues

\begin{tabular}{l|l}
\hline Architecture & $\begin{array}{l}\text { Central principles, policies and institutions that guide sustainable } \\
\text { groundwater use and protect groundwater quality, and interactions between } \\
\text { them }\end{array}$ \\
\hline Access and use & $\begin{array}{l}\text { Institutions and procedures that determine who has access to groundwater, for } \\
\text { what purposes and how groundwater is allocated }\end{array}$ \\
\hline Accountability & $\begin{array}{l}\text { Institutions and procedures that provide accountability for groundwater } \\
\text { protection and use }\end{array}$ \\
\hline Adaptation & $\begin{array}{l}\text { How groundwater users, governments and third parties respond and adapt to } \\
\text { changes and uncertainty in groundwater availability, use and governance }\end{array}$ \\
\hline Agency & Private and public sector responsibilities for groundwater management \\
\hline
\end{tabular}


The classification aligns with major themes of governance research and the framework has been subject to extensive peer review and has now been in use for several years.

\subsubsection{Architecture}

Groundwater extraction always creates an impact on other resources or the environment somewhere in a hydrological system. Before extracting groundwater a decision is required about the sustainable level of impact that can be accommodated by the system. A sustainable yield can be determined by a combination of two elements. Firstly, stakeholders negotiate a "consensus" or "acceptable" yield that enables them to set management goals. The acceptable yield may be defined in terms of specified resource condition targets. Secondly, scientists and engineers calculate the "operational" yield - the amount of groundwater available through different methods able to meet management goals (Richardson et al. 2011; Pierce et al. 2011). Decisions about acceptable groundwater yield and resource condition targets depend on political judgements about the weights that should be given to consumptive and environmental water consumption now and into the future.

The difficulty of establishing quality standards for groundwater increases with the variability of water quality and use over space and time. Groundwater quality regulation requires definition of well-defined groundwater and environmental quality standards, indicators/measures that enable the achievement of those standards to be assessed, criteria against which the success or failure of specific groundwater protection strategies or interventions can be evaluated (e.g. compliance with environmental quality standards) and evaluation of those interventions (Quevauviller 2008).

\subsubsection{Access and Allocation}

Comprehensive, well defined, secure legal entitlements provide incentives for investment and collective water management (Ostrom 2005; Bruns et al. 2005). A distinction needs to be made between appropriation of groundwater for private use and provision of groundwater for public benefit. Water property rights give individuals an incentive to make the best use of groundwater for their individual purposes, but individuals do not have an incentive to provide groundwater for the environment or to take account of "external" impacts of their use on resources that are remote in space or time.

The collective allocation of entitlements to access and use groundwater is appropriate because of the common property nature of groundwater resources and the external impacts of their use. Collective allocation may be undertaken by elected governments or by other organisations that represent stakeholders, both water users and others. Access and allocation rules can be set out in legal 
documents such as in water plans, or more informally in local agreements (Tang 1992).

Water allocation describes the process that sets out how, by whom and on what basis decisions are made about access to and use of water (Turner et al. 2004). Water allocation processes take place on different sectoral and administrative scales. Allocation refers to both the allocation of groundwater, and also responsibilities and risks related to groundwater management. Clear allocation principles and priorities are particularly important to deal with water scarcities.

Groundwater allocation can be assessed in terms of its effectiveness, efficiency and fairness. Effectiveness is indicated by whether water allocations are sustainable and meet quality standards. Efficiency is indicated by whether groundwater is allocated or can be transferred to its most economically efficient use. Fairness is indicated by whether people and communities have access to water of acceptable quality to meet their needs. The allocation of groundwater access and use entitlements is complicated by variation in legal authorities across administrative boundaries, conflicts between competing users and uncertainties about future biophysical and social conditions (Blomquist et al. 2004). The agriculture sector is the main user of groundwater in many countries, but many cities depend on groundwater. As agriculture develops and cities grow the access and allocation of groundwater becomes more challenging.

\subsubsection{Accountability}

Two important aspects of accountability can be distinguished. Democratic accountability refers to the institutions and procedures that provide public accountability for groundwater abstraction and groundwater quality standards. Technical accountability refers to processes of monitoring and reporting about groundwater condition and use. Both forms of accountability occur at multiple geographical and administrative scales.

Accountability and legitimacy issues have become increasingly important given the increasing complexity of groundwater management organisations, which include private actors and networks as well as elected governments. When central government agencies govern groundwater they are democratically accountable to the government of the country. However, centralised government agencies may be disconnected from water users and communities, who may perceive government decisions as not being consultative or legitimate (Gross 2011). When groundwater is governed by non-government bodies such as water user groups or watershed partnerships the lines of accountability are less clear. Such bodies may give disproportionate influence to particular groups such as farmers but may also offer opportunities for developing deliberative processes that are genuinely engage citizens (Huitema and Meijerink 2012).

Accountability requires the effective measurement and monitoring of groundwater use. This requires the installation of meters on individual wells and collation of use data by managing bodies - government or non-government. Measurement, 
monitoring and reporting of groundwater use is complicated by the large number and diffuse nature of groundwater users, and by the fact that many of the impacts of groundwater use only become evident after many years (Moench 2007). In many countries, the data available on both groundwater quantity and quality are poor and not standardised compared to the data available for surface water (Biswas 1999).

\subsubsection{Adaptation}

Adaptation can be encouraged by institutional design or implementation processes. Institutional adaptation allows for learning and change in response to unforeseen situations, such as unexpectedly severe droughts or floods, and changing knowledge and policy (Walters 1986; Pahl-Wostl 2007). Regulatory instruments and long-term plans provide direction and certainty to water users but they can be relatively inflexible in responding to change. Flexibility mechanisms such as adjustable shares of volumetric water entitlements, carryover arrangements, water trading and leasing have been built-in to groundwater regulations and plans in Australia and the Western USA to improve adaptability (Ross 2012).

Adaptation is also encouraged by collaborative groundwater governance processes that allow governments, water users and independent experts to collectively learn, negotiate and co-produce groundwater management arrangements (Emerson et al. 2012). It is not sufficient to get feedback through public seminars and discussions. Ongoing engagement of and effective collaboration between policy makers, scientists and practitioners is required (Letcher and Jakeman 2002).

\subsubsection{Agency}

A large variety of non-government as well as government organisations have been given authority to establish and implement groundwater policies and standards in different jurisdictions. Groundwater governance involves a large number of individuals and agencies exercising a wide range of roles and responsibilities. Groundwater governance has often been criticised as being too fragmented, including too many agencies with unclear roles and responsibilities. However attempts to streamline groundwater governance have proved difficult because of the wide diversity in groundwater resource and user attributes.

Groundwater governance poses a cross scale management dilemma. High-level governments can provide effective control, cross sectoral coordination and accountability, and can act flexibly to solve crises. However, hierarchical management can become very complicated at the river basin or sub-basin scale and may displace stakeholder and community action. Moreover, local governments and water users often understand groundwater resources and their importance to communities and the environment better than central governments (Ross 2012).

Special-purpose organisations, such as catchment management organisations in Australia and water districts in the USA may provide a better match with 
hydrogeological boundaries, better local coordination, and encourage engagement and innovation (Marshall 2005; Cech 2010). However, local organisations lack knowledge and incentives to manage intertemporal impacts of resource use at a river basin scale (Schlager 2007), and sometimes lack public accountability.

\subsection{Groundwater Governance in Australia, the European Union and the Western United States}

\subsubsection{The Context for Groundwater Governance}

Increasing groundwater use in Australia, the EU and the USA underlines the importance of good groundwater governance. Groundwater provides about $17 \%$ of water used in Australia, and much higher percentages in some regions and/or during dry periods. Groundwater use is increasing rapidly. For example between 1993-1994 and 1996-1997 groundwater use tripled in New South Wales and Victoria, the most populous states in Eastern Australia (the Australian Government 2001). By 2030 average groundwater use in the Murray-Darling Basin - which includes the majority of Australia's irrigated agriculture, is estimated to increase from an average of $14 \%$ to $27 \%$ of the total water used (CSIRO 2008).

Groundwater supplies about $65 \%$ of public water supplies in Europe (Jacques 2004), and $23 \%$ of agricultural water. There are wide variations between the EU states with a much larger proportion of agricultural water coming from groundwater in southern Europe (EASAC 2010). In many rivers across Europe more than $50 \%$ of annual flow is derived from groundwater, and in dry periods this can rise to more than $90 \%$ (European Commission 2008).

In 2000 groundwater provided about $20 \%$ of water consumed in the USA, $37 \%$ of public supply withdrawals and $51 \%$ of drinking water. There is substantial variation between the states, and in the arid Western USA there is substantial water scarcity, groundwater over drafting and related problems including land subsidence, saltwater intrusion and pollution. Groundwater use for irrigation has increased substantially. In 1950 only $23 \%$ of irrigation withdrawals were groundwater, by 2000 groundwater's share had risen to $42 \%$ (Kenney et al. 2009).

\subsubsection{Key Elements of Groundwater Governance in Australia, the EU and the Western USA}

Key elements of governance architecture, allocation and access, accountability, adaptation and agency in Australia, EU and the Western USA are summarised in Table 6.2 and described in the following sections of this chapter. 
Table 6.2 Key elements of groundwater governance in Australia, the EU and the Western USA

\begin{tabular}{|c|c|c|c|}
\hline & Australia & EU & Western USA \\
\hline Architecture & $\begin{array}{l}\text { National Water } \\
\text { Initiative (NWI) } \\
\text { Tradable property } \\
\text { rights } \\
\text { Water plans } \\
\text { Drinking water } \\
\text { standards }\end{array}$ & $\begin{array}{l}\text { EU water framework } \\
\text { directive (WfD) } \\
\text { Groundwater quantity } \\
\text { and quality standards } \\
\text { River basin } \\
\text { management plans }\end{array}$ & $\begin{array}{l}\text { No national strategy } \\
\text { Tradable property rights } \\
\text { Augmentation/ } \\
\text { mitigation plans } \\
\text { Drinking water } \\
\text { standards }\end{array}$ \\
\hline $\begin{array}{l}\text { Allocation and } \\
\text { access }\end{array}$ & $\begin{array}{l}\text { Return overallocated } \\
\text { basins to sustainable } \\
\text { use }\end{array}$ & $\begin{array}{l}\text { Maintain good } \\
\text { groundwater condition } \\
\text { (quantity and quality) }\end{array}$ & $\begin{array}{l}\text { Maintain property rights } \\
\text { of senior (surface water) } \\
\text { users - prior } \\
\text { appropriation system }\end{array}$ \\
\hline Accountability & $\begin{array}{l}\text { NWI consultation } \\
\text { principle } \\
\text { National monitoring of } \\
\text { NWI, State monitoring } \\
\text { of water plans }\end{array}$ & $\begin{array}{l}\text { WFD consultation } \\
\text { principle } \\
\text { Reporting on river } \\
\text { basin plans }\end{array}$ & $\begin{array}{l}\text { No national } \\
\text { accountability except for } \\
\text { drinking water standards }\end{array}$ \\
\hline Adaptation & $\begin{array}{l}\text { Variable "share" } \\
\text { allocations } \\
\text { Water markets }\end{array}$ & $\begin{array}{l}\text { EU/National drought } \\
\text { management plans } \\
\text { Flexible } \\
\text { implementation of } \\
\text { WFD }\end{array}$ & $\begin{array}{l}\text { Water "rationing" by } \\
\text { means of prior } \\
\text { appropriation system } \\
\text { Flexible implementation } \\
\text { of prior appropriation }\end{array}$ \\
\hline Agency & $\begin{array}{l}\text { Centralised } \\
\text { governance }\end{array}$ & $\begin{array}{l}\text { Subsidiarity principle } \\
\text { Wide range of national } \\
\text { settings }\end{array}$ & $\begin{array}{l}\text { Emphasis on local } \\
\text { governance by courts } \\
\text { and water users } \\
\text { monitored by States }\end{array}$ \\
\hline
\end{tabular}

\subsection{Governance Architecture: Principles, Policies and Institutions}

Australia and the EU have both adopted broad scale (continental) water management strategies with embedded groundwater components. The USA has not adopted a single comprehensive water management strategy and relies on a more decentralised approach using historical water allocation norms and principles prior appropriation in the case of the Western USA. Groundwater governance in Europe is largely based on regulation, Australia has developed a mixed system of regulation and markets, the USA has a polycentric groundwater governance system with a mixture of instruments.

\subsubsection{Australia}

Groundwater management in Australia has been strongly influenced the trajectory of surface water reform. Principles for water governance in Australia are contained in the 1994 and 2004 Council of Australian Government (COAG) agreements on 
water reform. The 1994 COAG agreement included full cost recovery, separation of water from land titles, integrated catchment management and the establishment of water markets and trading (COAG 2004). The 2004 Intergovernmental Agreement on a National Water Initiative (NWI), included the establishment of secure water access entitlements, water access planning with provision for environmental and other public benefit outcomes, the return of over allocated systems to sustainable levels of extraction and further development of water markets, best practice water pricing and national water accounting.

Section 23 of the NWI provides for "a nationally consistent market, regulatory and planning based system for managing surface water and groundwater resources", while 23 (x) recognises "the connectivity between surface and groundwater resources and connected systems managed as a single resource". Surface water and groundwater for human consumption and the environment are managed within this framework but water quality is managed separately.

Under Australia's federal system of government, the primary right to own or to control and use water is vested with the States and Territories (Lucy 2008). The States and Territories have enacted "mirror" legislation to incorporate the NWI in state laws and regulations. Groundwater is allocated in accordance with priorities established by the State governments. The 1992 Murray-Darling Basin agreement placed a cap on surface water use (MDBC 2006), and included a formula for allocating water among MDB jurisdictions, but there was no similar cap on groundwater use, which continued to expand for a further decade.

The Australian Government's Water Act 2007 requires that the new MurrayDarling Basin Authority prepare an integrated surface and groundwater plan for the basin. The Basin Plan was passed by the Australian Parliament on 26 November 2012. The plan includes sustainable diversion limits for groundwater resources, but these have been criticised insufficiently recognising surface water groundwater connectivity and for failing to take account of environmental impacts of groundwater pumping (Nelson 2012).

Groundwater quality is not included as a central objective or element in the NWI. Water quality is subject to a separate agreements between Australian governments, including the National Action Plan for Salinity and Water Quality and the National Water Quality Management Strategy (NWQMS). The NWQMS contains detailed standards for water that is to be used for specific human consumptive purposes, which are included in state legislation, but groundwater quality monitoring is generally poor. Groundwater salinity is increasing and groundwater dependent ecosystems are threatened by over-extraction and poor groundwater quality in some areas. Nitrate levels in some irrigated catchments exceed national drinking water standards and ecosystem protection guidelines (Geoscience Australia 2010). 


\subsubsection{The European Union (EU)}

The European Water Framework Directive (WFD) developed from a series of earlier water directives which were driven by concerns to ensure clean water supplies and to maintain environmental quality in the EU. The WFD is a legally binding policy that provides a common framework for integrated management of the quality of all types of water in Europe. The WFD came into force in December 2000.

The primary objectives of the WFD are to protect and enhance water quality and aquatic ecosystems and to promote sustainable water use. The WFD includes five key elements; river basin management based on river basin plans, a combined approach to pollution control linking emission limit values to environmental quality standards, definition of "good water status", the principle of full cost recovery for water and increasing public participation in policy making (Page and Kaika 2003). Good water status includes a focus on ecological status for surface water and quantitative status for groundwater i.e. groundwater levels linked to the achievement of ecological objectives (Wijnen et al. 2012).

The WFD is a supranational law which had to be transposed into domestic law of the EU Member States. Parts of the WFD, especially the chemical status of water bodies and the so-called priority substances contain specified standards. Environmental standards have been set for surface water for 33 substances. The ecological goal-setting process allows member states considerable freedom regarding both policy process and policy output, e.g. targets and end goals for water bodies. Implementation is flexible in several important ways including the designation of the relative "modification" of water bodies, the degree of formalisation of goals and environmental standards, scale of implementation, stakeholder participation, integration with other policy fields, and finally exemptions from general targets (Liefferink et al. 2011). If member states fail to transpose the WFD the European commission can initiate an infringement procedure before the European Court of Justice which may impose financial penalties (Mechlem 2012).

The WFD (Article 4.1(b) (i and ii) require member states to implement all measures necessary to prevent or limit the input of pollutants into groundwater, to prevent the deterioration of the status of all bodies of groundwater, and to protect enhanced and restore all bodies of groundwater, ensuring a balance between abstraction and recharge with the aim of achieving good groundwater status within 15 years.

Groundwater provisions of the WFD require member states to define and characterise groundwater bodies (within river basin districts), identify bodies at risk of not meeting WFD objectives, establish registers of areas where groundwater requires protection, establish groundwater threshold values (quality standards), pollution trends, and measures to prevent or limit inputs of pollutants into groundwater. Implementation of these provisions includes establishment of monitoring networks, and inclusion of groundwater protection in river basin management plans and programs of measures for achieving WFD objectives for each river basin district (European Commission 2008). 
River basin management plans were due to be submitted to the Commission by 2009 and programs of measures have to be in force by the end of 2013. However, there are large differences between member states in the enforcement of EU standards. More than $50 \%$ of groundwater bodies in some southern European states are at risk of not meeting WFP requirements because of the overpumping and pollution (EASAC 2010).

\subsubsection{Western USA}

There is no overarching national strategic framework for water management in the United States or across the western USA. Water for human use and the environment, and water quantity and water quality objectives are managed separately. Each individual state has "plenary control" over the waters within its boundaries and state of local governments set goals for regulating water use and water pollution.

In the Western USA the doctrine of prior appropriation was developed to set water allocation priorities and to address disputes among landowners. The doctrine includes four key elements; establishment of a water right by diverting water and applying it to a beneficial use, and (once beneficial use was established) the right to exclude others from using the same water, to use the water in allocation distant from the source and to sell the water to third parties (Jones and Cech 2009). Subsequently most western states adopted groundwater legislation that extended the doctrine to cover groundwater (Schlager 2006).

State law underpins the doctrine of prior appropriation (Kenney et al. 2005). If low stream flows prevent senior rights holders from diverting the water to which they are entitled, the seniors put a "call" on the river, requiring all upstream rights holders "junior" to the caller to stop diverting water until adequate streamflow is restored (Howe 2008). In the prior appropriation system most groundwater rights holders are relatively junior and have to make good their impacts on senior rights holders. In times of water scarcity this can result in groundwater pumping being terminated (Jones 2010).

Groundwater drawdowns and pollution have led to the choice between reducing the take of existing users or restricting new development. In some cases groundwater users have successfully lobbied against restrictions leading to the ongoing depletion of resources such as the High Plains aquifer (Sophocleous 2009).

The US Federal government has had a strong involvement in water development and distribution, through major water projects and more recently through federal environmental law (Kenney et al. 2005).

The Federal Clean Water Act (s102) provides for the development of comprehensive programs for preventing, reducing or eliminating the pollution of groundwater used for human consumption. The Act (s106) also allows for funding to support groundwater protection programs but in practice the costs of remediating source water pollution are met by municipal governments and industry (GWPC 2007). Federal pollution control laws including the Resource Conservation and Recovery Act and the Comprehensive Environmental Response Compensation and 
Liability Act provide for landowners to be liable for point source pollution including impacts on groundwater (Smith 2004). The Endangered Species Act provides for the conservation of threatened and endangered plants and animals and their Habitats, and is an important driver for environmental water provision.

Application of prior appropriation to groundwater has not prevented groundwater depletion in unconnected basins, while in connected basins it has prevented the use of groundwater when surface water is scarce (Schlager 2006), Groundwater quality controls are largely limited to point source pollution and sources of drinking water, there are no systematic controls on diffuse pollution. Thomas (2009) argues that the US would benefit from the adoption of a federal approach similar to the EU groundwater directive to protect its groundwater resources.

\subsection{Access and Allocation}

\subsubsection{Australia}

Under the NWI Australia has adopted a framework of water entitlements that are completely and transparently defined, separated from land wherever possible, specified in registers, monitored and enforced (NWC 2009). Entitlements to access water, to take water in a particular season/year and to use water at a particular place and time for a specific purpose are separated from land ownership.

Surface water allocations are made to satisfy these entitlements in each season/ year as defined in the relevant State water plan and depending on the amount of water available. During scarcities lower priority agricultural uses receive less than the face value of their water entitlement. In most Australian jurisdictions the separation of water entitlements from land promotes the development of water markets and trade in water.

The allocation of shares of total available groundwater is more difficult to clearly define. Groundwater availability is often defined according to proportion of longterm recharge that can be extracted without compromising the integrity of the water source and the ecosystems and communities that depend on it.

The use of groundwater has been restricted in a limited number of management areas on the basis of exploitation of, or stress in surface and/or groundwater resources. In some highly exploited stressed groundwater systems, annual allocations of a share of water entitlements have allowed authorities to control groundwater exploitation without compulsory reduction of entitlements (NWC 2006). Cease to pump rules are applied to some groundwater resources to maintain minimum flows in connected streams. However, there is no systematic national approach.

The efficient allocation of resources has been boosted by the development of water markets but the effectiveness of the protection of groundwater resources is complicated by the overallocation of water use entitlements (Young 2010), and the failure to properly account for impacts on groundwater use of surface water 
resources (Evans 2007). There are a range of community perceptions about fairness in water allocation, in particular there is some disagreement about the balance of allocations between water for the environment and irrigation (Connell et al. 2007).

\subsubsection{The EU}

In the EU the entitlement to use water is generally given by public authorities through licences and permits. Water allocation is carried out by different authorities and agencies at different levels. Authority to pump groundwater is generally given through permits that refer to the quantity of water abstracted and/or pumping capacity. Permits are issued for varying periods of time in different states. In some states including France, Germany and the UK environmental impacts are considered when granting permits.

National authorities have powers to restrict abstractions during times of water scarcity or drought. Some countries such as Netherlands, Spain and France determine restrictions according to a hierarchy of water users. Priority may also be given to particular sectors, or sometimes within sectors, for example for specific crops (European Commission 2012).

Also the WFD sets a "good quantitative status" for groundwater which implies an obligation to ensure a balance between (natural) recharge and abstraction over a river basin management cycle. However, the implementation of the programme of action that has followed the groundwater directive has concentrated on water quality issues rather than over abstraction.

Regulation of groundwater has not kept pace with the rapid growth in groundwater use in terms of both users and volumes used. Different member states use different combinations of instruments to manage groundwater resources. In some parts of the EU land-use control is the main instrument. For example in the UK environmental agencies have defined source protection zones for some 2000 groundwater sources. In many parts of the EU there are regimes for groundwater protection including the licensing of boreholes. However, in many of the southern European states the number of unlicensed users is growing rapidly (EASAC 2010).

The effectiveness of the Water Framework Directive is being reduced by slow implementation because of the different degrees of ambition and cohesion of the efforts of member states (Liefferink et al. 2011), and technical challenges including information processing (Hering et al. 2010). In southern Europe where the economic and social dependence on groundwater takes precedence over ecological considerations a difficult balance has to be struck between the social benefits of current consumption and the broader social and ecological benefits of conserving water dependent ecosystems (EASAC 2010). European water markets for quality or quantity are not well developed, reflecting a European emphasis on administrative water allocation and regulations on water quality. These institutions may be relatively efficient for European conditions, but there are opportunities for markets that can deliver greater amounts of cleaner water at lower costs (Zetland 2011). 


\subsubsection{The Western USA}

In the Western USA groundwater access and allocation has been regulated by the operation of the prior appropriation system. Water access and allocation reflects common-law courts decisions from the late 19th and early twentieth century. Surface water rights are generally senior to groundwater rights.

Prior appropriation has worked differently when applied to aquifers compared to surface waters. It has also applied differently to groundwater resources unconnected to surface water (non-tributary) and connected (tributary) resources (Schlager 2006).

In the case of non-tributary groundwater priority acts to limit the number of well permits issued but does not prevent declining water tables. Reasonable declines in water tables are allowed. It is up to state courts to determine what constitutes a reasonable decline on a case-by-case basis. State governments have not intervened to limit the issue of well permits until aquifer depletion and/or negative impacts on other users have become serious. In the case of tributary groundwater, prior appropriation has been adapted to allow some groundwater pumping while protecting senior surface rights. Groundwater pumpers have been allowed to pump water if they can provide water to augment stream flows to prevent injury to surface water users (or the environment). This system prevents long-term over abstraction of tributary groundwater, but it can discourage efficiency because water is forfeited if it is not used within the statutory time period (Neuman 2010) and it prevents the use of groundwater during droughts when it is most needed (Schlager 2006).

Further modifications of state water allocations based on prior appropriation have been needed to allow for the fact that hydrologic systems do not stop at state boundaries (GWPC 2007) and pumping can harm senior water rights in adjoining states. In order to deal with this problem interstate agreements have been negotiated to address cross-border impacts of water use.

Environmental water allocation is managed separately from water for consumptive use and the fairness of the prior appropriation system can be challenged in the sense that it does not service changing social preferences such as environmental water requirements. Federal environmental laws including the Clean Water Act and the Endangered Species Act provide the main driver for environmental water provision, often through an interstate compact. For example, the South Platte Compact requires that between April 1 and October 15 Colorado must ensure river flows do not fall below $120 \mathrm{cfs} .{ }^{1}$ Colorado has also committed to making 10,000 acre feet of water available between April and September of each year to assist recovery programs for three endangered birds and one endangered fish (Freeman 2011).

\footnotetext{
${ }^{1} 100$ cubic feet per second equals 2.82 cubic metres per second.
} 


\subsection{Accountability}

\subsubsection{Australia}

In Australia there are several levels of democratic accountability for groundwater management. The National Water Commission (NWC) has responsibility for reviewing the implementation of the NWI and reporting to the Australian government. The NWC has published biennial reviews of the NWI. State and Territory water authorities have responsibility for establishing groundwater management plans, and monitoring and enforcing these plans. These authorities report progress to their own government and also to the NWC.

The NWI provides that governments engage water users and other stakeholders in water planning and other reform processes in order to improve certainty and confidence, transparency and information sharing. State water legislation includes provision for consultation in relation to water plans, but consultation often appears more symbolic than real, because it takes place after policy changes have been made and/or does not take sufficient account of stakeholder views (Bowmer 2003). Australian and international experiences show how communities can use collaborative water planning processes to manage cuts to water allocations (Richardson et al. 2011) and for flood and drought risk management (Daniell et al. 2010).

The NWI requires all jurisdictions to ensure adequate measurement, monitoring and reporting systems are in place. The capacity of State and Territory governments to monitor groundwater resources and plans is mixed. Some resources, especially the most highly exploited resources, have relatively good metering and monitoring, but many resources lack basic metering, measurement and monitoring infrastructure. There is a national program to develop this infrastructure. Monitoring of groundwater quality is limited and carried out in an ad hoc manner. There is no consistent national program on groundwater quality monitoring and much of the monitoring has been short term (Geoscience Australia 2010).

\subsubsection{The EU}

Democratic accountability for the implementation of the WFD is complex with local areas reporting to national governments and parliaments who in turn report to the European Community and Parliament. EU member states and the European commission have jointly developed a Common Implementation Strategy (CIS) for supporting the implementation of the WFD. A Strategic Coordination Group (SCG) composed of Member States and stakeholder organisations coordinates cooperation on implementation.

Groundwater planning and allocation systems have high levels of democratic accountability to national governments, and the European Parliament, but sometimes are not perceived as legitimate at local levels because of lack of community participation and deliberative processes. The WFD requires governments to provide information about planned measures and to report on implementation to 
stakeholders and the general public. It remains a challenge to ensure public access to reliable and consistent information about measures, and to motivate and facilitate public participation (De Stefano et al. 2013).

The SCG has developed guidance documents on groundwater monitoring and groundwater protected areas and is developing guidance on compliance and impacts of land use on groundwater. Measurement, metering and monitoring capability varies substantially among the EU member states, and between regions within the states. EU wide coverage and long-term series of water quality data are not available, and the analysis of water quantity is insufficient in many river basin plans - only $25 \%$ of plans include water availability scenarios and less than $20 \%$ assess data uncertainty.

\subsubsection{Western USA}

State governments are accountable for groundwater management. There is no national accountability mechanism except in the case of transboundary aquifers where there are interstate agreements, and where federal courts or the Supreme Court are responsible for the agreements.

Water management in the US is fragmented, with many overlapping jurisdictions and agencies. Stakeholder engagement, information sharing and accountability is effective across parts of the system but it is very difficult to ensure good communication and consultation across the whole system. Groundwater is governed by a network of water users, water courts and administrative authorities. Groundwater management arrangements are accountable and are perceived as legitimate at a local level, but are not necessarily democratically accountable or perceived as legitimate at a broader level.

There are many gaps in information about groundwater availability and use and there is a need to improve the effectiveness of coordination of groundwater information and data. There is no regular national review or monitoring of groundwater use. The US Geological Service issues periodic reports. The latest covered groundwater use in 2010 (Maupin et al. 2014).

The Clean Water Act (s 106(e)) requires the USEPA to determine that a state is monitoring water quality including groundwater. Thirty states have included some groundwater monitoring in their water monitoring strategies but most of the emphasis is on surface water monitoring. ${ }^{2}$ From 1991 the US Geological Survey (USGS) has implemented a National Water Quality Assessment Program that includes groundwater assessments. The USGS has identified 62 regionally extensive aquifers and is carrying out assessments of about one third of them, but most aquifer assessment and monitoring is carried out by the states, and the quality of the programs is highly variable (GWPC 2007).

\footnotetext{
${ }^{2}$ GWPC-NGWA survey of State groundwater programs, 2006.
} 


\subsubsection{Monitoring - A Common Challenge}

Australia, Europe and the Western USA face similar technical accountability challenges because of shortfalls in groundwater metering and monitoring infrastructure. It is difficult to centrally manage groundwater monitoring because groundwater abstraction is very diffuse. On the other hand groundwater users and local governments often have insufficient mandate or resources to put broadscale monitoring programs in place.

\subsection{Adaptation}

\subsubsection{Australia}

Section 25 (iv) of the NWI provides for adaptive management of surface water and groundwater systems in order to meet productive, environmental and other public benefit outcomes. The National Water Commission undertakes biennial reviews of the implementation of the NWI, but it is left for states to determine how often to review water plans in their jurisdictions. Under the new Murray-Darling Basin plan the Murray-Darling Basin Authority will review state water resource plans, which will usually have a 10 year life cycle. ${ }^{3}$

In the Murray-Darling Basin flexibility is introduced into water allocation in three ways. Firstly water is allocated to entitlement holders on an annual basis depending on water availability. Secondly surface water and groundwater entitlement holders have a limited capacity to carryover water entitlements for later use. Thirdly, surface water and groundwater trading provides some extra flexibility for water users, including the potential to purchase additional water to make up shortfalls in allocations during dry periods, if there is water available for purchase. However, groundwater trading volumes have been relatively small in the MurrayDarling Basin and there has been no recorded surface water and groundwater trading (Ross 2012).

\subsubsection{The EU}

The EU WFD adopts an adaptive water planning approach. National water authorities adopt management plans, including quality standards and programs of measures for water districts for 6-year periods. These plans are monitored and evaluated and the WFD recognises that quality standards and programs of measures may need to be modified in the following 6-year period. However, the legal systems of some member states are not sufficiently flexible to respond to new situations and information.

\footnotetext{
${ }^{3}$ http://www.mdba.gov.au/draft-basin-plan/delivering-healthy-working-basin/ch03. Accessed 5 April 2013.
} 
The WFD recognises the importance of adaptive mechanisms but they are dealt with through parallel processes including the EU water scarcity and drought policy developments. In 2007 the European Commission released a communication on water scarcity and droughts that laid down a water hierarchy including demand management followed by alternative supply options once the potential for improving water efficiency had been exhausted. This text is, however, not legally binding.

A Commission review of this policy (European Commission 2012) found that while member states have established mechanisms for authorising groundwater use, illegal abstractions remain an important challenge in some parts of Europe. There has been only limited implementation of drought risk management plans, and cost recovery and price incentive mechanisms.

In practice the main flexibility mechanism in the WFD is the degree of freedom given to member states to set groundwater standards and implementation timetables. This approach reflects heterogeneity in the member states, but could result in slow improvements in standards which would reduce the effectiveness of the WFD.

\subsubsection{Western USA}

The prior appropriation system deals with uncertain water supply and shortages by setting clear priorities for allocation of scarce water based on seniority. Junior water entitlement holders must relinquish water in times of shortage. This system provides certainty in the face of changing water supplies but is not very flexible in responding to changing social preferences for the use of water such as demand for new urban development, provision for in stream flows or conjunctive water management. In addition conflicts are resolved by litigation which can be slow and not very responsive to unanticipated crises needing urgent responses.

Adaptive management is gaining a foothold in some agencies like the National Marine Fisheries Service and the U.S. Forest Service, but state water management agencies have a restricted role and responsibilities, to manage the allocation of water for consumptive use or to control water to ensure consumptive supplies. Water quality and water for the environment are managed separately. Because of these management settings water management agencies are not at the forefront of strategic adaptive management (Neuman 2010), although they do provide some leadership in information collection, monitoring and the development of local water allocation plans (Wolfe 2008).

In practice the law of prior appropriation has included provisions for reducing allocations of water to users in response to risks including water scarcity, wasteful or non-beneficial use or displacement by "public rights". On the other hand junior entitlement holders including municipalities and groundwater groups have obtained enough political power to secure continued allocations (Tarlock 2001). For example, local water plans in Colorado have enabled flexible implementation of the prior appropriation system, without requiring junior groundwater entitlement holders to 
cease production, except in the most extreme drought conditions (Blomquist et al. 2004).

Water trading and leasing provide further flexibility mechanisms. In Colorado there is a significant amount of water trading, mainly transfers from agricultural to municipal users (Howe and Goemans 2003). Water leasing has enabled farmers to lease part of their water portfolio to municipalities and to reduce their acreage temporarily through crop rotation or fallowing (Pritchett et al. 2008).

\subsection{Agency}

\subsubsection{Australia}

Historically, surface water and groundwater planning, rule development and administration have been separated in Australian jurisdictions. The historical separation of surface water and groundwater science (hydrology and hydrogeology) has reinforced the administrative separation. These separations have hindered the development of integrated water management. Water management and allocation in the Australian states is highly centralised in the hands of responsible ministers and their departments. Surface water and groundwater policy and planning are coordinated at the highest levels of decision-making, but often separate at lower levels.

Government representatives generally consider that policy and implementation functions are integrated effectively. But some water users consider that state water managers do not provide enough information and that some functions are poorly integrated. For example, in the Namoi region in New South Wales, users cited as examples of poor integration the separation of management of overland flows, stock and domestic bores, and issues related to water in the mining sector from other water planning and allocation processes. Local and regional bodies could play a more effective role in water planning and management if there were increased delegation of responsibility to these bodies, increased funding or fund raising capacity and support from high level leadership.

\subsubsection{The EU}

The EU Water Framework Directive initiated the move from national and local water management towards river basin planning, but generally EU member states adapted existing management and administrative bodies to implement the WFD maintaining long-standing water management institutions.

Groundwater governance in Europe is generally coordinated by national authorities, sometimes concentrated at the level of member states and sometimes decentralised to regional and local levels. There is a large diversity of management organisations. Many small states such as Denmark have a relatively top-down approach, whereas the large states exhibit a greater diversity of multilevel 
governance agencies. In Denmark the Minister for Environment is responsible for river basin management plans, whereas in the Netherlands the competent authority is the Minister for Transport, Water Management and Public Works. In the Netherlands regional water authorities and water boards have a strong role in implementing the WFD.

River basin authorities have a leading role in a small number of member states. France had already adopted a river basin approach before the WFD was conceived and adapted the existing structure of the river basin and sub-basin plans to implement the WFD (Liefferink et al. 2011). Water user groups play an important role in a limited number of countries including Spain. European countries will benefit from continued experiments with groundwater governance and representation from different levels of government, water users and experts.

\subsubsection{Western USA}

Federal water-related agencies and programs are fragmented and require better coordination. More than 30 federal agencies, boards, and commissions in the United States have water-related programs and responsibilities (Christian Smith et al. 2012). The allocation and distribution of water is subject to regulation by state water resource agencies, and is ultimately in the hands of thousands of farmers, hundreds of irrigation districts and a large number of municipalities and industries.

Local groundwater supply and distribution is managed by regional and local water entities, such as mutual water user companies and cooperatives, irrigation districts, conservancy and conservation districts. These organisations provide a crucial link between state laws and policies and individual water users. In some states water districts play an important role in encouraging regional coordination and innovation. In most cases organisation members democratically establish policy and elect management Boards. The organisations are non profit and raise revenue by assessments on shares (mutual companies), on acreage allotments (irrigation districts), or taxes on land or water sharing assessments (conservancy districts) (Freeman 2000). Municipal users and irrigators initiated the South Platte Water Related Activities Program to ensure that instream flow and endangered species obligations are met (Freeman 2011).

Decentralised groundwater management in the Western USA has encouraged many institutional innovations but management effectiveness could be could be improved by strategic watershed planning that integrated consumptive and environmental requirements, and gave governments and water users an opportunity to adjust the prior appropriation doctrine in order to achieve improved water management outcomes. 


\subsubsection{The Influence of Vested Interests}

In all three regions historically powerful water authorities and water users exert substantial influence and sometimes resist change. The protection of groundwater dependent ecosystems is an ongoing challenge. Strong leadership and broad community engagement are needed to progress reforms in groundwater management.

\subsection{Comparative Assessment of Groundwater Governance in Australia, the EU and the Western USA}

Drawing on the analysis in the previous section the main strengths and weaknesses in groundwater governance in Australia and the EU and the Western USA are summarised in Table 6.3.

Table 6.3 Strengths (+) and weaknesses (-) of groundwater (GW) governance in Australia, the EU and the Western USA

\begin{tabular}{|c|c|c|c|c|}
\hline & & Australia & EU & Western USA \\
\hline \multirow[t]{2}{*}{ Architecture } & + & $\begin{array}{l}\text { NWI provides for } \\
\text { comprehensive GW } \\
\text { governance }\end{array}$ & $\begin{array}{l}\text { WFD provides } \\
\text { comprehensive } \\
\text { GW protection }\end{array}$ & $\begin{array}{l}\text { Prior appropriation } \\
\text { system safeguards } \\
\text { senior water rights }\end{array}$ \\
\hline & - & $\begin{array}{l}\text { Weak GW quality } \\
\text { regulation (except for } \\
\text { drinking water) }\end{array}$ & $\begin{array}{l}\text { Variable } \\
\text { implementation of } \\
\text { GW standards }\end{array}$ & $\begin{array}{l}\text { Weak GW quality } \\
\text { regulation (except for } \\
\text { drinking water) }\end{array}$ \\
\hline \multirow[t]{2}{*}{$\begin{array}{l}\text { Access and } \\
\text { allocation }\end{array}$} & + & $\begin{array}{l}\text { Water plans set } \\
\text { sustainable GW use } \\
\text { limits }\end{array}$ & $\begin{array}{l}\text { GW allocation } \\
\text { included in river } \\
\text { basin plans }\end{array}$ & $\begin{array}{l}\text { Effective rationing of } \\
\text { scarce water }\end{array}$ \\
\hline & - & $\begin{array}{l}\text { Overallocation of } \\
\text { GW use entitlements }\end{array}$ & $\begin{array}{l}\text { Variable } \\
\text { implementation of } \\
\text { basin plans }\end{array}$ & $\begin{array}{l}\text { GW overuse in some } \\
\text { areas }\end{array}$ \\
\hline \multirow[t]{2}{*}{ Accountability } & + & $\begin{array}{l}\text { Democratic } \\
\text { legitimacy }\end{array}$ & $\begin{array}{l}\text { Democratic } \\
\text { legitimacy }\end{array}$ & Local legitimacy \\
\hline & - & $\begin{array}{l}\text { Use monitoring } \\
\text { variable, quality } \\
\text { monitoring poor }\end{array}$ & $\begin{array}{l}\text { Variable } \\
\text { monitoring and } \\
\text { reporting }\end{array}$ & $\begin{array}{l}\text { Accountability for } \\
\text { impacts at large scales, } \\
\text { variable monitoring }\end{array}$ \\
\hline \multirow[t]{2}{*}{ Adaptation } & + & $\begin{array}{l}\text { Variable annual } \\
\text { water allocation }\end{array}$ & $\begin{array}{l}\text { Flexible } \\
\text { implementation of } \\
\text { EU standards }\end{array}$ & $\begin{array}{l}\text { Local innovation, } \\
\text { flexible enforcement of } \\
\text { prior appropriation }\end{array}$ \\
\hline & - & $\begin{array}{l}\text { Centralised system } \\
\text { can discourage local } \\
\text { innovation }\end{array}$ & $\begin{array}{l}\text { Slow } \\
\text { implementation of } \\
\text { drought } \\
\text { management plans }\end{array}$ & $\begin{array}{l}\text { Rigidity of prior } \\
\text { appropriation during } \\
\text { droughts }\end{array}$ \\
\hline \multirow[t]{2}{*}{ Agency } & + & $\begin{array}{l}\text { Central coordination } \\
\text { and planning }\end{array}$ & $\begin{array}{l}\text { Central } \\
\text { coordination and } \\
\text { planning }\end{array}$ & $\begin{array}{l}\text { Local empowerment } \\
\text { and innovation }\end{array}$ \\
\hline & - & $\begin{array}{l}\text { Local delegation and } \\
\text { implementation }\end{array}$ & $\begin{array}{l}\text { Local delegation } \\
\text { (in most countries) }\end{array}$ & Strategic planning \\
\hline
\end{tabular}


The EU WFD has gone furthest towards an integrated framework to manage groundwater quantity and quality objectives and human and environmental uses of groundwater. The discretion for member states to set their own standards and implementation timetable provides flexibility but also threatens to undermine effectiveness of the WFD. Australia's comprehensive system of water entitlements and related water markets together with annual adjustment of entitlement shares provides security and flexibility for consumptive users and encourages efficient water allocation. But it is not yet clear how successfully environmental water allocations can be integrated within this framework. The system of prior appropriation in the Western US provides clearly defined priorities for water allocation, but lacks flexibility during extreme droughts. Neither the Australian nor the US systems effectively protect groundwater quality or groundwater dependent ecosystems.

Australia, the EU and the Western USA face common groundwater governance challenges. Firstly, the effectiveness of policy and plan implementation varies substantially within the regions. Secondly, there are substantial knowledge gaps, measurement and monitoring is expensive and is highly variable. Thirdly, powerful stakeholders conspire to prevent change when it threatens their interests.

\subsection{Some Groundwater Governance Difficulties and Dilemmas}

Experience with groundwater governance in the EU, Australia and the Western USA raises some unresolved dilemmas relating to relationships between aspects of groundwater governance.

\section{Is a Comprehensive Integrated Groundwater Governance Architecture Feasible or Desirable?}

A comprehensive system of groundwater governance would integrate the management of groundwater quantity and quality for consumptive and environmental purposes. Only the EU WFD attempts to integrate all four elements. This has proved to be an ambitious goal, and in practice full integration has not been achieved. In Australia the management of groundwater quantity and quality is carried out by separate institutions and in the Western USA all four elements are separated, with variable degrees of coordination in different regions. Degrees of separation of the four elements may be acceptable providing that there are effective coordination mechanisms, which raises the question of what those mechanisms would be.

\section{What Coordination Arrangements Are Appropriate for Groundwater Governance?}

Groundwater governance involves some particular coordination challenges. Firstly, groundwater resources and user groups are very diverse. Different management rules are appropriate for different resources and users. For example different rules will be appropriate for a shallow alluvial aquifer highly connected to a river 
compared with a fractured rock aquifer remotely connected with surface water. Secondly, the boundaries of groundwater resources, their flows and their interactions with surface water and the environment are often not well understood. Hence centralised groundwater governance can be very complicated, and groundwater governance is typically organised at multiple geographical, sectoral and jurisdictional scales. A multilevel groundwater governance model including elements of central control and accountability, together with decentralised, participative local agencies is discussed below.

Thirdly, long-term coordination raises special difficulties. The impacts of groundwater use on other resources and the environment can be delayed by many years, decades or even centuries. When long-term impacts are discounted using a "market" discount rate long term impacts have a negligible value. This implies that long-term impacts of groundwater overuse will be considered relatively unimportant compared to short-term impacts, and the maintenance of long-term stocks of groundwater will be considered less important than preserving jobs and environmental icon sites. If discount rates were chosen by means of a deliberative process involving commercial developers, community representatives and user groups as well as governments chosen rate could be lower (or higher) than the average market rate. Community discounting is not the current practice and could be expensive but it could better reflect community views and aspirations for the future (Ross 2012).

\section{How Can Central Control and Stability Be Balanced with Adaptiveness?}

Well defined, secure entitlements and rules about the use of groundwater increase confidence in and support for groundwater management. At the same time mechanisms that allow the flexible use, storage and exchange of groundwater over time are required to optimise groundwater use in response to changes in climatic and market conditions and new knowledge. There are some working examples of arrangements that combine security and flexibility. The allocation of tradable water entitlements coupled with annual calculation of water available to be used by water entitlement holders has proved to be an effective means of responding to drought in Australia, but requires the prior issue of individual tradable water entitlements - without overallocation. The wide variety of innovations introduced by water districts and communities in the Western United States show the potential for decentralised collaborative groundwater management, although these institutions may lack broad democratic accountability.

\section{How Can Central Direction Setting and Coordination Be Balanced with Local Agency and Responsibility for Groundwater Governance?}

In practice groundwater governance is typically polycentric, involving a network of governments and their agencies, and special purpose organisations. Participation by groundwater users in decision making is necessary to ensure that users understand each other and have the opportunity to craft mutually acceptable management arrangements taking account of relevant information and uncertainties (Emerson et al. 2012; Ross 2012). This can be achieved by a multilevel approach including both jurisdictional and/or basin wide overviews of water resources and uses and 
detailed management arrangements for individual resources. This multilevel approach can avoid the difficulties involved in drafting and communicating a fully detailed management plan at the river basin or jurisdictional scale, but at the same time ensure a coordinated approach to water management consistent with broader social and policy goals. Higher level governments will need to overcome their reluctance to give control to decentralized organisations (Marshall 2005; Ross 2008).

\subsection{Conclusions}

In this chapter groundwater governance in the EU, Australia and the Western USA has been compared using an analytical framework drawn from the Earth System Governance Project. While the high-level international comparison yields some interesting results, the analysis masks many regional and local variations in the study regions.

The EU WFD has gone furthest towards an integrated framework to manage groundwater quantity and quality objectives, but there are many implementation challenges. Australia's system of water entitlements and water markets coupled with variable annual water allocations provides security and flexibility for consumptive users. But neither it nor the US system protect GDEs or prevent diffuse pollution of groundwater. While the US system provides clearly defined priorities for water allocation, it lacks flexibility during extreme droughts.

Fully integrated management of all sources of water, as intended by the WFD, is a very ambitious goal. The advantages of a strong central direction and coordination together with decentralised local management might be obtained through collaborative planning and management at sub-basin scales nested within an overarching groundwater planning framework at the jurisdictional or basin scale. This system could take various forms in different countries depending on social preferences and institutional settings and capacity.

Open Access This chapter is distributed under the terms of the Creative Commons AttributionNoncommercial 2.5 License (http://creativecommons.org/licenses/by-nc/2.5/) which permits any noncommercial use, distribution, and reproduction in any medium, provided the original author(s) and source are credited.

The images or other third party material in this chapter are included in the work's Creative Commons license, unless indicated otherwise in the credit line; if such material is not included in the work's Creative Commons license and the respective action is not permitted by statutory regulation, users will need to obtain permission from the license holder to duplicate, adapt or reproduce the material.

\section{References}

Australian Government (2001) Australian water resources assessment 2000. National Land and Water Resources Audit, AGPS, Canberra 
Biermann F et al (2009) People, places and the planet: science and implementation plan of the earth system governance project. IHDP, Bonn

Biswas A (1999) Water crisis: current perceptions and future realities. In: Salman M, Salman A (eds) Groundwater-legal and policy perspectives, vol 456, World bank technical paper number. The World Bank, Washington, DC

Blomquist W, Schlager E (2008) Embracing watershed politics. University of Colorado Press, Boulder

Blomquist W, Schlager E, Heikkila T (2004) Common waters diverging streams. Resources for the Future, Washington, DC

Bowmer K (2003) Look after the land and the rivers: reflections on water sharing. Keynote paper 28th international hydrology and water resources symposium. The Institution of Engineers, Wollongong

Bruns B, Ringler C, Meinzem-Dick R (eds) (2005) Water rights reform: lessons for institutional design. International Food Policy Research Institute, Washington, DC

Cech T (2010) Written statement of Tom Cech, Executive director of the Central Colorado Water Conservancy District concerning managing water for the future: how federal, state and local entities are supporting agriculture. In: Sub-Committees of water and power of the house Committee on natural resources, US House of Representatives, Greeley, 17 May 2010

Connell D, Robins L, Dovers S (2007) Delivering the national water initiative: institutional roles, responsibilities and capacities. In: Hussey K, Dovers S (eds) Water for Australia: the social and institutional challenges. CSIRO, Canberra

Council of Australian Governments (2004) Intergovernmental agreement on the national water initiative. Council of Australian Governments, Canberra

CSIRO (2008) Water availability in the Murray-Darling Basin: a report from CSIRO to the Australian Government. CSIRO, Canberra

Daniell K et al (2010) Co-engineering participatory water management processes: insights from Australia and Bulgaria. Ecol Soc 15(4): Art 11

De Stefano L et al (2013) Easier said than done? The establishment of baseline groundwater conditions for the implementation of the water framework directive in Spain. Water Res Manage 27(7):2691-2707

Emerson K et al (2012) An integrated framework for collaborative governance. Public Adm Res Theory 22(1):1-29

European Academy's Science Advisory Council (2010) Groundwater in the southern member states of the European Union, and an assessment of current knowledge and future prospects, German National Academy of Sciences. EASAC Secretariat, Halle

European Commission (2008) Groundwater protection in Europe: the new groundwater directive consolidating the EU regulatory framework. European Commission, Luxembourg

European Commission (2012) Communication from the Commission to the European Parliament, the Council the European Economic and Social Committee and the Committee of the Regions: report on the review of the European water scarcity and droughts policy. COM (2012) 672, Brussels

Evans R (2007) The impact of groundwater use on Australia's rivers. Land and Water Australia, Canberra

Foster S, Garduno H (2013) Groundwater-resource governance: are governments and stakeholders responding to the challenge. Hydrogeol J 21:317-320

Foster S et al (2009) Groundwater governance: conceptual framework for assessment of provisions and needs, GW-MATE strategic overview series 1. World Bank, Washington, DC

Freeman D (2000) Wicked water problems: sociology and local water organisations in addressing water resource policy. J Am Water Resour Assoc 36(3):483-491

Freeman D (2011) Implementing the Endangered Species Act in the Platte Basin water commons. University Press of Colorado, Boulder

GEF, World Bank, UNESCO-IHP, FAO, IAH (2015) Global diagnostic on groundwater governance. http://www.fao.org/fileadmin/user_upload/groundwatergovernance/docs/general/ GWG_VISION.pdf. Accessed 10 June 2015 
Geoscience Australia (2010) Assessing the need to revise the guidelines for groundwater protection in Australia: a review report. Geoscience Australia, Canberra

Gross C (2011) Why justice is important. In: Connell D, Quentin Grafton R (eds) Basin futures. ANU Press, Canberra

Ground Water Protection Council (2007) Groundwater report to the nation: a call to action. Ground Water Protection Council, Oklahoma City

Hering D et al (2010) The European water framework directive at the age of 10: a critical review of the achievements with recommendations for the future. Sci Total Environ 408(19):4007-4019

Howe C (2008) Water law and economics: an assessment of river calls and the South Platte well shut down. Univ Denver Water Law Rev 12:181-196

Howe C, Goemans C (2003) Water transfers and the impacts: lessons from three Colorado water markets. J Am Water Resour Assoc 39(5):1055-1065

Huitema D, Meijerink S (2012) The politics of river basin organisations: coalitions, institutional design choices and consequences. In: Lund conference on earth system governance, 18-20 Apr 2012, Lund

Jacques P (2004) Introduction: Western Europe. In: Brentwood M, Robar S (eds) Managing common pool groundwater resources: an international perspective. Praeger, Westport

Jones A (2010) South Platte Well Crisis, 2002-2010. In the water report. Envirotech Publications, Eugene

Jones PA, Cech T (2009) Colorado water law for non-lawyers. University Press of Colorado, Boulder

Kenney D et al (eds) (2005) In search of sustainable water management: international lessons for the American west and beyond. Edward Elgar, Cheltenham

Kenney J et al (2009) Estimated use of water in the United States in 2005, circular 1344. US Department of the Interior, US Geological Survey, Washington, DC

Letcher RA, Jakeman AJ (2002) Experiences in an integrated assessment of water allocation issues in the Namoi river catchment, Australia. In: Rizzoli A, Jakeman A (eds) Proceedings of the 1st biennial meeting of the International Environmental Modelling and Software Society (iEMSs), Lugano

Liefferink D et al (2011) The EU water framework directive: a multi-dimensional analysis of implementation and domestic impact. Land Use Policy 28:712-722

Lucy J (2008) Water regulation: the laws of Australia. Thomson Reuters Australia Ltd, Sydney

Marshall G (2005) Economics for collaborative environment management: renegotiating the commons. Earthscan, London

Maupin MA et al (2014) Estimated use of water in the United States in 2010: U.S. Geological Survey Circular 1405, $56 \mathrm{p}$

Mechlem K (2012) Groundwater governance: a global framework for action: thematic paper 6: legal and institutional frameworks. FAO, Rome

Moench M (2004) Groundwater: the challenge of monitoring and management. In: Gleick P (ed) The world's water; the Biennial report on the world's water resources 2004-05. Island Press, Washington

Moench M (2007) When the well runs dry but livelihood continues: adaptive responses to groundwater depletion and strategies for mitigating the associated impacts. In: Giodarno M, Villholth K (eds) Agricultural groundwater revolution opportunities and threats to development. CABI International, Colombo

Murray Darling Basin Commission (2006) Murray Darling Basin agreement. Murray Darling Basin Commission, Canberra

National Water Commission (2006) 2005 National competition policy assessment of water reform progress. National Water Commission, Canberra

National Water Commission (2009) Australian water reform 2009: second biennial assessment of progress in implementation of the national water initiative. National Water Commission, Canberra 
Nelson R (2012) Submission to house of representatives standing committee on regional Australia's inquiry on certain matters relating to the proposed Murray Darling Basin plan: groundwater SDLs. Parliament of Australia, Canberra

Neuman J (2010) Are we there yet? Weary travellers on the long road to water policy reform. Nat Resour J 50:139-166

Ostrom E (1990) Governing the commons: the evolution of institutions for collective action. Cambridge University Press, Cambridge

Ostrom E (2005) Understanding institutional diversity. Princeton University Press, Princeton

Ostrom E, Gardner R, Walker J (1994) Rules, games and common-pool resources. The University of Michigan Press, Ann Arbor

Page B, Kaika M (2003) The EU water framework directive: part 2 policy innovation and the shifting choreography of governance. Eur Environ 13:328-343

Pahl-Wostl C (2007) Requirements for adaptive water management. In: Pahl-Wostl C, Kabat P, Moltgen J (eds) Adaptive and integrated water management: coping with complexity and uncertainty. Springer, Berlin

Pierce $\mathrm{S}$ et al (2011) Aquifer-yield continuum as a guide and typology for science-based groundwater management. Hydrogeol J 21:331-340

Pritchett J, Thorvaldson J, Frasier M (2008) Water as a crop: limited irrigation and water leasing in Colorado. Rev Agric Econ 30(3):435-444

Quevauviller P (2008) Groundwater science and policy: an international overview. The Royal Society of Chemistry, Cambridge

Richardson S et al (2011) Connecting science and engagement, and setting groundwater extraction limits using a stakeholder led decision-making process. In: Connell D, Quentin Grafton R (eds) Basin futures. ANU Press, Canberra

Ross A (2008) Australia. In: Jordan A, Lenschow A (eds) Innovation in environment policy: integrating the environment for sustainability. Edward Elgar, Cheltenham

Ross A (2012) Water connecting people adapting: integrated surface water and groundwater management in the Murray-Darling Basin, Colorado and Idaho. Australian National University, Canberra

Schlager E (2006) Challenges of governing groundwater in US western states. Hydrogeol J $14: 350-360$

Schlager E (2007) Community management of groundwater. In: Giordano M, Villholth K (eds) The agricultural groundwater revolution: opportunities and threats to development. CABI Publishing, Wallingford

Smith Z (2004) Groundwater: the US experience. In: Brentwood M, Robar S (eds) Managing common pool groundwater resources: an international perspective. Praeger, Westport

Sophocleous M (2009) Review: groundwater management practices, challenges, and innovations in the High Plains aquifer USA-lessons and recommended actions. Hydrogeol J 18:559-575

Tang SY (1992) Institutions and collective action: self-governance in irrigation. ICS Press, Lanham

Tarlock AD (2001) The future of prior appropriation in the new west. Nat Res Law J 41(4):761793

Thomas R (2009) The European directive on the protection of groundwater: a model for the United States. Pace J Environ Law 26:260-287

Turner K et al (2004) Economic evaluation of water resources in agriculture: from the sectoral to a functional perspective on natural resources management. FAO, Rome

Walters C (1986) Adaptive management of renewable resources. Macmillan, New York

Wijnen $\mathrm{M}$ et al (2012) Managing the invisible: understanding and improving groundwater governance. World Bank, Washington, DC

Wolfe D (2008) The future of water administration in Colorado. CBA-CLE, Denver

Young M (2010) Environmental effectiveness and economic efficiency of water use in agriculture: the experience of and lessons from the Australian water reform programme. OECD, Paris

Zetland D (2011) Water markets in Europe. Water Resour Impact 13(5):15-18 